\begin{tabular}{|c|c|c|c|}
\hline $\begin{array}{l}\text { KULTURA } \\
\text { i } \\
\text { SPOHFCTF木'TTWO }\end{array}$ & $\begin{array}{l}\text { POLSKA } \\
\text { KOMITET } \\
\text { INSTYTUT }\end{array}$ & $\begin{array}{l}\text { AKADEMIA NAUK } \\
\text { SOCJOLOGII } \\
\text { T STUDIÓW POLITYCZNYCH }\end{array}$ & ISSN 0023-5172 \\
\hline SPULCLLNSIMU & 2015, nr 1 & CZYTAJĄC ELIASA & \\
\hline
\end{tabular}

BORYS CYMBROWSKI

Uniwersytet Opolski

\title{
WALKA KLAS W SPOŁECZEŃSTWIE DWORSKIM
}

Zamierzam tu poświęcić uwagę problematyce zróżnicowania społecznego poruszanej w stosunkowo mało znanej w Polsce (bo wciąż nieprzetłumaczonej) pracy Norberta Eliasa Die höfische Gesellschaft („Społeczeństwo dworskie”). Bezsprzecznie należy ona do ważniejszych dzieł tego autora. Zawiera wykład na temat kształtowania się figuracji dworskiej — szczególnego układu stosunków społecznych i struktury władzy, z którego wyrósł francuski absolutyzm. Jest to jedna $z$ tych prac Eliasa, które mieszczą się $w$ tradycji socjologii historycznej. Pragnę pokazać, że historyczna interpretacja powstawania i rozwoju absolutystycznej monarchii francuskiej od połowy XVI do XVIII wieku jest także opisem dynamiki przemian struktury społecznej. W tym celu niezbędne jest odtworzenie Eliasowskiego ujęcia - pokazanie, w jaki sposób zorganizowana była hierarchia na dworze królewskim, jakiego rodzaju stosunki społeczne były dla niej charakterystyczne. Zidentyfikowawszy tarcia zachodzace w tej strukturze, porównam je do walk klasowych opisywanych przez Karola Marksa (zwłaszcza w początkowym okresie twórczości) i wyciągnę wnioski dotyczące charakterystyki zróżnicowań społecznych w ujęciu zaproponowanym przez Eliasa. Następnie postaram się dokonać ekstrapolacji tego sposobu widzenia i zaproponować figuracyjne spojrzenie na dynamikę zróżnicowania społecznego jako szczególnie przydatne do analizy procesów przemian społecznych.

Powstawanie aparatu władzy doby absolutyzmu i leżąca u jego podstaw struktura społeczna elit to jedno $z$ tych zagadnień, które nurtowały Eliasa przez całe życie (powracał do nich wielokrotnie). Marksa natomiast, zwłaszcza 
w młodości, zajmowało powstawanie i utrwalanie się formacji burżuazyjnej — proces towarzyszący słabnięciu porządku społecznego, który Elias określił jako „społeczeństwo" czy też „towarzystwo dworskie”. Nie bez znaczenia pozostaje z pewnością fakt, że powstanie „dworu” jako społecznego zaplecza monarchii absolutystycznej zbiega się z ukonstytuowaniem się kapitalizmu jako systemu społeczno-gospodarczego. W połowie XIX wieku zaś mieliśmy do czynienia ze społecznymi wstrząsami, które towarzyszyły dalszym przekształceniom kapitalizmu, znajdującego się już $\mathrm{w}$ fazie rozwiniętej.

\section{INSPIRACJE KRYTYCZNE ELIASA}

Znamienne jest, iż Elias swoją koncepcję procesu cywilizacji starał się usytuować po mi ę d z y dwiema innymi wielkimi krytycznymi teoriami, Sigmunda Freuda i Marksa ${ }^{1}$. Fakt ten jest znaczący - wskazuje bowiem na to, że Elias chciał, by jego teoria procesu cywilizacji traktowana była jako jedna $z$ teorii krytycznych (por. Bogner 1987). Marksizm (w jego różnych odmianach) to koncepcja szczególny nacisk kładąca na procesy zbiorowe, zwłaszcza takie, które mają charakter masowy, w skrócie - makrospołeczne. Psychoanaliza zaś akcentuje zależności na poziomie jednostkowym. Samo więc usytuowanie podejścia Eliasowskiego może sugerować, że proces cywilizacji rozgrywa się gdzieś pomiędzy tymi dwoma poziomami: między widzianymi w perspektywie masowej stosunkami społecznymi, które da się ująć w formule walki klas, a stosunkami jednostkowymi, takimi, które kształtują osobowość człowieka. W kontekście procesu cywilizacji rzeczywistość społeczna jest czymś pośrednim, czymś, co ma zarazem charakter jednostkowy, jak i zbiorowy; co więcej - czymś, co jest w stanie pogodzić wymiar indywidualny $z$ wymiarem kolektywnym stosunku społecznego.

Inspiracje Marksowskie, nawet jeśli Elias traktował pisarstwo Marksa, a zwłaszcza jego kontynuacje, ze sporą dozą krytycyzmu, w jego pokoleniu były czymś zupełnie naturalnym. Lata szkolne Eliasa oraz początek jego studiów to czas, gdy niemiecki ruch robotniczy znajdował się w fazie dynamicznego rozwoju. Ponadto doświadczenie Wielkiej Wojny i jej przegrana przez Wilhelma II spowodowały rewolucję robotniczą i, przynajmniej częściowe, wprowadzenie ustroju socjalistycznego w Republice Weimarskiej. Z Marksem w różnych relacjach pozostawali autorzy, z którymi Elias musiał się liczyć jako młody naukowiec, poszukujący własnej ścieżki. Zarówno Max Weber (który, jak wiemy,

\footnotetext{
${ }^{1}$ Fakt ten na konferencji „Norbert Elias and figurational sociology” (Kopenhaga, kwiecień 2012) przypomniał prof. Søren Nagbøl z Uniwersytetu w Aarhus, który w 1978 roku na Uniwersytecie we Frankfurcie nad Menem uczęszczał na wykład Eliasa, zatytułowany „Teoria cywilizacji w świetle psychoanalizy Freuda i teorii społeczeństwa Marksa" (zob. Nagbøl 2012, s. 103). Na powinowactwo myśli Eliasa $z$ koncepcjami Marksa i Freuda zwracają uwagę też inni autorzy (powinowactwo z Freudem - zob. Kuzmics 1987, s. 519-523; powinowactwo z Marksem - zob. Szakolczai 2005, s. 831; nieujawniane inspiracje u klasyków — zob. Marody 2008, s. XVI).
} 
starał się skorygować Marksowską analizę struktury społecznej) (Löwith 1993; Kozyr-Kowalski 1967, 1979; Käsler 2010, s. 221), jak i jego konkurent, Werner Sombart, znajdowali się stosunkowo blisko kwestii, które Marks uczynił ważnymi ${ }^{2}$. W zasadzie cała ówczesna niemiecka socjologia starała się odpowiadać na ogólne pytania, które postawił Marks. Stosunki Eliasa ze szkołą frankfurcką - jednym z najważniejszych ośrodków, w których rozwijana była intelektualna spuścizna Marksa - mają pośredni charakter, ale warto wspomnieć, że pośrednikiem w tej relacji był Karl Mannheim. Jego dzieło Ideologia $i$ utopia jest pracą, w której znajdziemy i wątki Marksowskie, i pewne podobieństwo do założeń procesu cywilizacji, rozwijanych w późniejszym czasie przez Eliasa ${ }^{3}$.

Przejmując Weberowskie inspiracje nie mógł Elias ominąć tych wątków Marksowskich, do których Weber nawiązywał. Po rewolucji październikowej w Rosji i rewolucji listopadowej w Niemczech w naukach społecznych gorąco dyskutowano problemy struktury klasowej i perspektywy rewolucji, strukturalne uwarunkowania działalności politycznej — jednym słowem: zagadnienia, które leżały w polu zainteresowań inicjatora międzynarodowego ruchu rewolucyjnego.

Co interesowało Eliasa? W pracy doktorskiej, napisanej we Wrocławiu pod kierunkiem Richarda Hönigswalda, opisuje on uwikłania jednostkowe w procesy dziejowe ${ }^{4}$. W dalszych pracach koncentruje się na problematyce uwikłania jednostki w strukturę społeczną. Do prac Eliasa o centralnym znaczeniu można zaliczyć jego największe dzieła: Die höfische Gesellschaft 5 i $O$ procesie cywilizacji (por. Bucholc 2013, s. 35).

\section{TOWARZYSTWO CZY SPOŁECZEŃSTWO DWORSKIE?}

Słowo Gesellschaft ma wiele odpowiedników w polszczyźnie. Najczęściej tłumaczone jest jako „społeczeństwo”. Jednocześnie znaczenie tego słowa rozciąga się na obszar życia zbiorowego, który po polsku oddany jest najlepiej za pomocą słów „spółka”, „stowarzyszenie” czy „towarzystwo” 6 . Zbiorowość

\footnotetext{
2 Nie tylko oni. Problemy te bliskie były całemu środowisku intelektualistów, przezywanych „socjalistami zza katedry” (Kathedersozialisten) — reformatorów społecznych, skupionych w Towarzystwie Reformy Społecznej (Verein für Socialpolitik) i publikujących między innymi w „Archiv für Sozialwissenschaft und Sozialpolitik".

$3 \mathrm{U}$ obu autorów inspiracja ta nie pozostawała bez związku z kontaktami z Alfredem Weberem (zob. Kilminster 2007, s. 40-70; Bucholc 2013, s. 17).

4 Tytuł pracy doktorskiej Eliasa brzmiał: „Idee und Individuum. Eine kritische Untersuchung zum Begriff der Geschichte” („Idea a jednostka. Krytyczne badanie nad pojęciem dziejów”).

${ }^{5}$ Praca napisana jako rozprawa habilitacyjna pt. „Der höfische Mensch. Ein Beitrag zur Soziologie des Hofes, der höfischen Gesellschaft und des absoluten Königtums” („Człowiek dworski. Przyczynek do socjologii dworu, dworskiego towarzystwa i absolutnej królewskości”) w roku 1933, w formie książkowej ukazała się dopiero w roku 1969; zob. Elias 2002.

6 Por. Max Weber, Wirtschaft und Gesellschaft („Gospodarka i społeczeństwo”), niemniej jednak nawet w literaturze socjologicznej pojawiają się inne odpowiedniki: „spółka”, „stowarzyszenie”.
} 
znających się osobiście dworzan otaczających króla, który sprawuje „władzę absolutną", być może lepiej byłoby oddać przez sformułowanie „towarzystwo dworskie". Współgrałoby to $z$ innymi określeniami związanymi z tą kategorią społeczną, takimi jak „damy z towarzystwa”, „dobre towarzystwo” itp. Jednak sformułowanie „społeczeństwo dworskie” wskazuje na pewne ogólnospołeczne konsekwencje. Dwór w opisywanej przez Eliasa epoce stanowił centrum zarządzania państwem. Jak w soczewce odbijały się tam wszystkie problemy państwa i to właśnie tam zapadały wszystkie decyzje. Kraj (czy może lepiej prowincja - obszar władzy króla, który znajduje się poza dworem) w XVI wieku zaczął stanowić dla króla zupełnie drugorzędny obszar działania. Ze względów praktycznych ilekroć przywoływany będzie tytuł tej książki Eliasa, będę stosował określenie „Społeczeństwo dworskie”. Wydaje się, że właśnie taka wersja tytułu jest bardziej odpowiednia w dyskusjach osób badających dorobek Eliasa i wykorzystujących założenia teoretyczne przezeń sformułowane ${ }^{7}$. Dwuznaczność słowa Gesellschaft w pojęciu höfische Gesellschaft wskazuje na dwa konteksty: "towarzystwo" ma bardziej wymiar interakcji między jednostkami i w kontekście książki Eliasa odnosi się ściśle do kręgów dworskich. „Społeczeństwo” natomiast wskazuje, że stosunki cechujące figurację dworską rzutują na stosunki w całym społeczeństwie; „socjologia dworu” dotyczy „towarzystwa” jako pierwotnego obszaru działania króla, „społeczeństwo” zaś wskazuje, że stosunki panujące w "towarzystwie" rzutują na stosunki panujące w całym kraju. Pojęcie „społeczeństwo dworskie” oddaje zatem specyfikę stosunków panujących w społeczeństwie doby absolutyzmu.

\section{OD WŁADZY PATRYMONIALNEJ DO ABSOLUTNEJ ALBO WALKA KLAS W SPOŁECZEŃSTWIE DWORSKIM}

Mimo że „Społeczeństwo dworskie” (1933) powstało wcześniej niż O procesie cywilizacji... (1939), to na wydanie musiało czekać aż trzydzieści lat. Czytając prace Eliasa warto o tym pamiętać — zachowanie chronologii powstawania tych prac pozwala na prześledzenie rozwoju pojęć teoretycznych, którymi posługuje się autor.

W „Społeczeństwie dworskim” ramę analityczną stanowi dla Eliasa to, co nazywa figuracją d worską. Jest to specyficzny układ stosunków społecznych panujących na absolutystycznym dworze monarszym. Figuracja dworska nie jest tożsama $z$ dworem jako takim; powstaje dopiero w pewnym momencie. Zaczyna się kształtować na dworze feudalnym (czyli jej początki sięgają powstania państwa Karolingów), ale właściwą sobie formę zaczyna przyjmować dopiero w początkach epoki nowożytnej. W XVI wieku królowie i ich świty

Istotne niech będzie to, że wszystkie te polskie odpowiedniki posiadają cechy definiujące Gesellschaft („stowarzyszenie”) w klasycznym ujęciu Ferdinanda Tönniesa (1988, s. 67).

7 Tą wersją spolszczonego tytułu posługuje się Mirosława Marody (2008, s. XII). 
przestają się przemieszczać. Po pierwsze, świadczy to o zmianie struktury społecznej: możliwe było kontrolowanie terytoriów bez powtarzającego się ich wizytowania; po drugie, o zmniejszeniu się roli szlachty, która przestawała być podstawą siły zbrojnej (rycerstwem). Po trzecie, w tym czasie w Europie Zachodniej emancypuje się mieszczaństwo, którego elity były w stanie obsługiwać finansowe interesy królów.

\section{DWÓR JAKO FIGURACJA}

W „Społeczeństwie dworskim” Norbert Elias przedstawia dwór jako specyficzną figurację. Figuracja to pojęcie naukowe, które pozostaje metaforą, i jako takie jest bardzo pojemne. Figurację tworzą jednostki ludzkie, ale także jednostki wraz z grupami społecznymi, z państwem narodowym włącznie (zob. Elias 2010, s. 13 i 33). Jest tym wyrazistsza, łatwiejsza do zauważenia, im trwalsza. Warto może przytoczyć tę definicję figuracji, która podkreśla jednocześnie trwałość i dynamiczność. Elias stosuje w tym celu porównanie do tańca:

„Obraz ruchomych układów, tworzonych przez współzależnych w tańcu ludzi, ułatwia wyobrażenie sobie jako figuracji państw, miast, rodzin lub też systemów kapitalistycznych, komunistycznych i feudalnych. Metafora ta przyczynia się do usunięcia przeciwstawienia, które pojawia się dziś zazwyczaj w podtekście, gdy ktoś używa pojęć «jednostka» $\mathrm{i}$ «społeczeństwo», a oparte jest na różnych sposobach wartościowania i ideałach" (Elias 2011, s. 64).

Tańcząca para to dwie jednostki, które pozostają względem siebie we względnie trwałej relacji; jako para stanowi autonomiczną całość, której relacje do otoczenia są w wysokim stopniu zmienne: przesuwając się po parkiecie mijają inne pary, meble, przemieszczają się po sali, jednak wzajemne relacje tych dwojga są trwałe, skoordynowane, zgrane. O tyle przynajmniej, by utrzymać równowagę.

Figuracja dworska to szczególny rodzaj figuracji. Jest to specyficznie dynamiczna forma stosunków społecznych, której wzorcową postać przypisuje Elias epoce Ludwika XIV (zresztą nie tylko on traktuje ją jako wzorzec; we współczesnej historiografii funkcjonuje ona jako model $\mathrm{w}$ zasadzie tożsamy $z$ typem idealnym $\mathrm{w}$ Weberowskim rozumieniu). Początek ma w feudalnym porządku patrymonialnym: „[K]ażdy Francuz widział w swym królu głowę własnej rodziny [...] Wśród szlachty i wyższej warstwy urzędniczej nie wolno było zawrzeć małżeństwa bez uprzedniej zgody króla. Zaniechanie tego kroku oznaczało to samo, co przystąpienie do rebelii. Król mógł nawet kojarzyć małżeństwa bez zgody, a nawet wbrew woli rodziców. Jego wola w takich przypadkach wystarczyła, by obezwładnić wszelki opór" - to cytat z niemieckiego historyka, Maxa von Boehna, który dobrze obrazuje relacje między królem a stanem szlacheckim i źródła lojalności wobec władcy. Co więcej, każdy szlachcic traktował króla jak swego osobistego znajomego (zob. Elias 2002, s. 76). 
Dla króla takiego jak Ludwik XIV — króla nowego typu — dwór stanowił „pierwotny obszar działania” (primärer Aktionsbereich). W typowej monarchii średniowiecza królowie nie potrzebowali dworu. Monarchowie osobiście dowodzili wojskiem i dzięki temu bezpośrednio oddziaływali na szlachtę, stanowiącą jego trzon. Jeszcze w epoce absolutyzmu takich monarchów nie brakowało w Europie. Nie potrzebowali oni dworu jako specyficznego zaplecza wykonywania władzy. Ludwik XIV oddziaływał przede wszystkim na swój dwór; kraj był sferą wtórną w stosunku do dworu. Król najpierw oddziaływał na dworzan, a ci dopiero później przekazywali dalej informacje, rozkazy, polecenia. I zwrotnie - przez filtr dworu musiała przejść każda informacja, zanim dotarła do króla (zob. Elias 2002, s. 77). Elias wskazuje, że właśnie ten fakt jest źródłem przekonania o nieograniczonej mocy władzy króla nad krajem i jego poddanymi. Socjologia dworu to jednocześnie „socjologia królewskości” (Soziologie des Königtums) (Elias 2002, s. 77).

Zasadnicza różnica między średniowiecznym społeczeństwem stanowym a społeczeństwem stanowym doby absolutyzmu polega na tym, że $\mathrm{w}$ tym pierwszym struktura władzy była $\mathrm{w}$ wysokim stopniu labilna, $\mathrm{w}$ drugim zaś dwór gwarantował jej niezwykle zaawansowaną stabilność (Elias 2002, s. 107). Struktura społeczna warstw dworskich francuskiego ancien régime'u jest ściśle zhierarchizowana i jednocześnie dynamiczna: nieustannie zachodzą w niej zmiany. Faktem niekwestionowanym pozostaje to, że na szczycie hierarchii stoi król. Następne w kolejności to: (1) arystokracja rycerska ${ }^{8}$ - wywodząca się ze średniowiecznych rodów rycerskich, (2) wyższy kler, (3) korpus wysokich urzędników sądów i administracji. Kolejne kategorie to średnia i niższa szlachta rycerska (fr. noblesse d'épée), średni i niższy kler oraz średni i niższy korpus urzędniczy. Należy pamiętać, że ten układ hierarchiczny nie ma charakteru typologicznego, członkowie społeczeństwa dworskiego realnie pozostają względem siebie w ściśle hierarchicznych stosunkach. Są to warstwy, które dysponują prawomocnością z mocy tradycji. Obok nich sytuują się financiers - mieszczanie, którzy bardzo się wzbogacili. Są wśród nich dzierżawcy podatków, którzy finansują państwowe inwestycje (Elias 2002, s. 107). $\mathrm{Ci}$ „maszerujący nieco z boku” - jak określa ich Elias - to przedstawiciele finansjery awansujący z szeregów warstw mieszczaństwa zawodowego do członków społeczności stanowej. Powoli nabywają specyficznych dla społeczeństwa stanowego sposobów myślenia (Elias 2002, s. 113). Awans społeczny tej warstwy nie jest bezprecedensowy: wcześniej szlak został przetarty przez magistratów (czyli urzędników sądownictwa). Magistratura od-

\footnotetext{
8 Elias nazywa ją arystokracją miecza (Schwertaristokratie), w nawiązaniu fo francuskiego terminu noblesse d'épée („szlachta miecza”). W dobie absolutyzmu przeciwstawia się ją szlachcie mieszczańskiego pochodzenia, której przedstawiciele wzbogaciwszy się byli przez króla uszlachcani i za opłatą obejmowali wysokie stanowiska urzędnicze. Ze względu na togę jako element stroju urzędniczego nazywani byli noblesse de robe (,szlachtą togi”).
} 
dzieliła się od mieszczaństwa we wcześniejszej fazie powstawania społeczeństwa dworskiego na początku XVII wieku, kariera financiers zaś to dopiero wiek XVIII. Przedstawiciele tej warstwy zyskują prawomocność dzięki decyzji króla.

Tu właśnie przydatne staje się figuracyjne spojrzenie na dwór królewski: tendencja kooptacji warstw mieszczańskich do środowiska dworskiego ma początek $\mathrm{w}$ zasadzie $\mathrm{w}$ tym samym czasie, kiedy zaczyna powstawać dwór jako zorganizowany aparat władzy, a nie tylko synonim świty króla - na początku XVII wieku, na długo przed wstąpieniem na tron Ludwika XIV. Figuracja dworska nie pozostała $\mathrm{w}$ niezmiennej formie. Był to proces, którego dynamika przybiera na sile. Jej źródłem są realnie występujące napięcia, do których dochodzi w społeczności dworskiej - w owym pierwszorzędnym obszarze działania króla. Monarcha stale zainteresowany mitygowaniem ambicji politycznych środowisk tradycyjnej szlachty rycerskiej, stale wciąga w orbitę swego bezpośredniego oddziaływania kolejnych bogatych mieszczan. Ci zaś, $\mathrm{w}$ przeciwieństwie do szlachty miecza, dysponują zasobami ekonomicznymi pochodzącymi z działalności mieszczańskiej. Świeżo uszlachceni mieszczanie przenikający do towarzystwa dworskiego w głównej mierze są przedstawicielami finansjery. Podstawowym, a w zasadzie jedynym, powodem, dla którego dostępują nobilitacji, jest ich bogactwo. Proces ten się nasila dlatego, że król łakomie spogląda na dostęp do pieniędzy, które przynoszą mu nowi szlachcice i dba o to, by nie brakowało kandydatów do nobilitacji. Jednocześnie rola „starej” szlachty stale się zmniejsza (Elias 2002, s. 113). Elias dostrzega nasilanie się tego procesu oraz pewne wahnięcia, rodzaje etapów, pokrywające się z różnymi okresami panowania Ludwika XIV oraz okresami rządów jego następców.

Przedstawiciele nowej arystokracji (noblesse de robe i financiers - właścicieli domów bankowych) nie mogli wnosić do społeczności dworskiej swych przyzwyczajeń, nawyków i ukształtowanych po mieszczańsku sposobów myślenia. Podlegali ścisłej etykiecie, której przestrzegano niezwykle rygorystycznie i która dzięki temu regulowała najdrobniejsze szczegóły interakcji; $\mathrm{w}$ ten sposób przejmowali dworskie sposoby komunikowania się. Etykieta w sztywny sposób ustawiała względem siebie poszczególne kategorie społeczne - poszczególne rangi w ramach społeczności dworskiej i określała $\mathrm{w}$ ten sposób panujące na dworze stosunki społeczne. Dostanie się do otoczenia króla, zostanie arystokratą, było marzeniem wielu mieszczan. Pozwala to domniemywać, że szlachcice $z$ mieszczańskim rodowodem ochoczo poddawali się tej etykiecie. Elias zauważa, że ta arystokracja $z$ awansu społecznego zmienia zakres wartości, porzuca pogardzany na dworze „interes” na rzecz „godności”, „honoru” i prestiżu, przyjmując całą gamę form mieszanych, przejściowych. Proces asymilacji przedstawicieli finansjery do społeczności dworskiej trwa jedno lub dwa pokolenia (Elias 2002 s. 113-114). 


\section{ARYSTOKRACJA I MIESZCZAŃSTWO: KONSUMPCJA A ŁAD SPOŁECZNY}

Życie dworu regulowała sztywna etykieta, jednoznacznie określająca szlachecki styl życia jako właściwy i prawomocny, jednak przekaz wartości między tradycyjną szlachtą a szlachtą wywodzącą się z mieszczaństwa wcale nie był jednostronny. Mieszczański styl życia wnoszony przez financiers powoli oddziałuje na tradycyjną szlachtę; moda, przyniesiona przez mieszczan do kół dworskich, W dużej mierze opiera się na wystawności. Tradycyjni arystokraci nie mogą się jej nie podporządkować, albowiem oznaczałoby to utratę prestiżu. To jest bardzo ważny mechanizm figuracji dworskiej. Właśnie dlatego król był w stanie utrzymywać swą pozycję arbitra i źródła prawomocności, że ekonomicznie osłabiał dworzan pochodzących z tradycyjnej szlachty o średniowiecznym, rycerskim rodowodzie i wprowadzał do tego środowiska mieszczan, którzy dość szybko tracili swój mieszczański etos społeczny (zob. Elias 2002, s. 114; więcej na ten temat: Baszkiewicz 1992, s. 228-230).

Elias kreśli podstawowe różnice kulturowe, które dzielą towarzystwo dworskie i kręgi wielkiej burżuazji (przede wszystkim finansjery), i zauważa, że normy społeczne, którym hołdują bourgeois, skoncentrowane są na pojedynczej rodzinie: rodzina jest jednostką ekonomiczną i ze względu na nią podejmuje się działania zorientowane na to, by wydatki nie przekraczały dochodów. $\mathrm{W}$ tych warstwach społecznych konsumpcja podlega kontroli. W wyniku „racjonalnego" gospodarowania powstaje różnica, którą można zainwestować, mając nadzieję, że dochody w przyszłości się zwiększą (Elias 2002, s. 116).

W warstwie dworskiej obowiązuje kulturowy wzór konsumowania na pokaz ${ }^{9}$. Elias nazywa ten sposób gospodarowania etosem konsumpcji prestiżowej. Przedstawiciele poszczególnych rodów arystokratycznych konkurują w tym zakresie między sobą, co prowadzi do rujnowania rodowych majątków. Realizacja takiego etosu wymaga specyficznej socjalizacji, a w wymiarze indywidualnym implikuje silne napięcia emocjonalne. Elias omawiając to zagadnienie przytacza cytat z Hipolita Taine'a (1881, s. 135-136), w którym autor przywołuje pewne praktyki wychowawcze, mające na celu nauczyć dzieci rozrzutności. Słowo „oszczędność” nie należało do wokabularza dworzan. Jeśli je wypowiadano, to zwykle $z$ odcieniem pogardy bądź jako epitet pod adresem szlachty mieszczańskiego pochodzenia (Elias 2002, s. 117). Widać tu paradoksalną sytuację; tradycyjni arystokraci nie są w stanie sprostać wymogom wystawnej konsumpcji, narzuconym przez uszlachconych bourgeois, ale piętnują oszczędność jako przywarę. Resentyment był odwzajemniony. Elias przywołuje w tym

\footnotetext{
${ }^{9} \mathrm{~W}$ książce znajduje się stosowny przypis do pracy Thorsteina Veblena oraz krytyczny komentarz. Elias twierdzi, że Veblen się myli, przypisując mieszczaństwu cechę pokazowej konsumpcji, pominął bowiem arystokrację, która konsumowała w znacznie większym stopniu. Później myśl tę rozwinął Pierre Bourdieu (2005) pokazując, że mieszczanie wzorowali swoje zachowanie na arystokratach.
} 
miejscu ironiczną wypowiedź Monteskiusza (który sam wywodził się z rodziny o mieszczańskich korzeniach) na temat szlachty rycerskiej. Zauważa, że osoby należące do tej warstwy pragną gromadzić majątek, lecz nie potrafią go nie trwonić. Utraciwszy swój stan posiadania, tracą zdolność obracania się w towarzystwie, robiąc $w$ ten sposób miejsce dla kolejnych rodzin chętnych, by je zająć, które z kolei poczynają marnotrawić to, co posiadają. Monteskiusz zwrócił uwagę także na podobieństwo łączące szlachtę miecza i szlachtę togi: był to całkowity zakaz zajmowania się handlem. Obie warstwy stanowiły przecież frakcje stanu szlacheckiego. Zakaz ten, według Monteskiusza, stanowił źródło monarchii absolutnej (Monteskiusz 1997, s. 192-193; por. Elias 2002, s. 119-121).

\section{MECHANIZM KRÓLEWSKI I ŁASKA MONARCHY}

Przedstawione zjawisko jest dość typowym przejawem krążenia elit. W tym jednak przypadku cyrkulacja elit stanowi element zmiany społecznej prowadzącej do upadku ustroju, jakim była monarchia absolutna. Szlachcice pochodzący z mieszczaństwa nie są traktowani przez szlachciców z rodowodem jako im równi, mają zatem poczucie deprywacji, przy czym dysponują większymi zasobami ekonomicznymi, dzięki czemu w mniejszym stopniu zależą od monarchy ( $z$ tego powodu to oni byli bardziej potrzebni królowi niż król im). W naturalny sposób zatem zainteresowani byli pogłębieniem zachodzących przemian. Poza tym pozostawali $\mathrm{w}$ stosunkach rodzinnych $\mathrm{z}$ mieszczanami, co $\mathrm{w}$ przypadku szlachty miecza samo w sobie było ujmą. Umiejętne wykorzystanie tego antagonizmu przez monarchę nazywa Elias „mechanizmem królewskim”. Obie grupy mają podobną siłę oddziaływania na króla — każda stara się przeciągnąć linę na swoją stronę, ale nie jest w stanie tego dokonać. Kompromis między nimi nie jest możliwy, bo sprzeczności interesów są zbyt duże. W tej sytuacji jeden człowiek, niebędący członkiem żadnej z tych grup, jest $\mathrm{w}$ stanie nadać dynamikę całej strukturze (Elias 2011, s. 446-447).

„Czas silnej władzy centralnej w społeczeństwie o wyższym stopniu zróżnicowania nadchodzi, gdy ambiwalencja interesów najważniejszych grup funkcjonalnych oraz układ ich sił są tak symetryczne, że nie jest możliwy ani trwały kompromis między nimi, ani otwarty, zakończony zwycięstwem jednej ze stron konflikt. Jedną $z$ konstelacji takiego typu jest zjawisko, które określamy tutaj mianem mechanizmu królewskiego" (Elias 2011, s. 443-444).

Zasadniczym elementem figuracji dworskiej było świadome utrzymywanie obu frakcji dworskich w stanie nieprzyjaźni. Gdyby obie te kategorie połączyły swoje siły, pozycja króla zostałaby zagrożona. Pełnia władzy królewskiej zależała od antagonizmu i zazdrości (Elias 2002, s. 122). Absolutystyczna aparatura panowania we Francji opiera się na mieszance sztywności i ruchliwości. Był to mechanizm utrzymywany w ruchu przez króla rozdającego tytuły szla- 
checkie bogatym rodzinom mieszczańskim, w wyniku czego rodziny te podporządkowywały się etosowi konsumowania statusowego (Elias 2002, s. 123). Dzięki etykiecie, która pozwala kontrolować ład społeczny, monarcha decyduje o pozycji każdego dworzanina. Każdy członek dworu może mieć dostęp do łaski króla. Zabieganie o nią jest koniecznością ekonomiczną. Ci, którzy się ową łaską cieszą, piastują urzędy dworskie, czerpią dochody z majątków nadanych im przez króla. Ci zaś, którzy łaski nie dostępują, popadają w ruinę - nie mając dochodów pozwalających na wydatki związane z życiem na poziomie, jakiego oczekuje towarzystwo dworskie, tracą wszystko (Elias 2002, s. 124).

Zabieganie o łaskę było na francuskim dworze mocno sformalizowane w postaci etykiety. Aby móc kontrolować przebieg procesów rywalizacji o łaskę, Ludwik XIV postanowił skupić działania te wokół siebie. To właśnie stanowiło przyczynę budowy kompleksu pałacowego w Wersalu, bo paryski Luwr nie był w stanie pomieścić całej dworskiej społeczności królestwa; Elias (2002, s. 139) podaje, że w połowie XVIII wieku w Wersalu mieszkało około dziesięciu tysięcy osób wraz ze służbą. Sam pałac oddaje w doskonały sposób strukturę społeczną dworskiego środowiska, w klarowny sposób odzwierciedlając złożoność zachodzących tam interakcji. Sypialnia króla znajdowała się na pierwszym piętrze głównego budynku, w środkowej części. Była usytuowana w taki sposób, że z okien roztaczał się widok na wszystkie, jeden za drugim, courts i avant-courts, co pozwalało w sposób symboliczny ogarnąć okiem całą dworską społeczność. Niektórzy autorzy uważają, że przeprowadzka Ludwika XIV do Wersalu (rok 1682) to właściwa cezura wyznaczająca początek absolutyzmu (por. Burke 2011, s. 17).

Oczywiście, formalizacja życia dworskiego nie została ustanowiona przez Ludwika XIV - istniała już wcześniej ${ }^{10}$. Etykieta dworska wynikała $z$ tego, że na dworze królewskim oraz w stylu życia warstw szlacheckich i arystokratycznych nie doszło do oddzielenia się sfery prywatnej od sfery publicznej. Dla króla i jego otoczenia zabawa była tyleż rozrywką, co oficjalnym spotkaniem, którego interakcje służyły odtwarzaniu i wytwarzaniu hierarchii społecznej. Była to sceneria, w której rozgrywał się spektakl zabiegania o królewską łaskę oraz okazywania bądź nieokazywania jej.

Wielkość panowania króla odbijała się w kształtowaniu jego funkcji domowych (Elias 2002, s. 142). Najdobitniej widać to w ceremoniach budzenia (lever) oraz kładzenia się spać (coucher) monarchy (a także w mniejszym stopniu innych członków rodziny królewskiej). „Bezpośrednio widać w nich, jak

\footnotetext{
10 Elias pisze o wczesnym ukształtowaniu się rytuałów dworskich jeszcze w XVI wieku, w czasach panowania Ludwika XIII, a na przykład Peter Burke (2011, s. 98), który nawiązuje do Eliasa, widzi źródło formalizacji reguł zachowania dworskiego w Hiszpanii. Tam proces ten miał się dokonać na początku XVII wieku, w czasach panowania Filipa IV, u którego późniejszy Król Słońce spędził sporo czasu w dzieciństwie.
} 
bardzo cechy władcy jako pana domu i króla stapiały się ze sobą" (Elias 2002, s. 142). Ceremonie sypialniane uznaje Elias za centralne dla figuracji dworskiej, ponieważ w nich wyraźnie uwidacznia się prestiż przypisany każdej z odgrywanych ról.

\section{BUDZENIE KRÓLA JAKO PAŃSTWOWY CEREMONIAŁ}

Tak prywatne, zdawałoby się, czynności jak poranna pobudka czy wieczorne kładzenie się spać na dworze Ludwika XIV były częścią ceremoniału politycznego, podczas którego król miał możliwość jednoznacznego okazania łaski (dopuszczając kogoś do uczestnictwa) lub niełaski (wykluczając kogoś lub przyznając mu mniej prestiżową rolę $\mathrm{w}$ ceremonii). Przywilej uczestniczenia w lever i coucher monarchy był ściśle zhierarchizowany — biorący w nich udział członkowie dworskiej elity potwierdzali swój status społeczny na dworze (por. Elias 2002, s. 143-144).

Peter Burke (2011, s. 21-22) w pracy na temat tworzenia wizerunku Ludwika XIV zwraca uwagę na teatralny wymiar tych rytuałów. Wiązały się one z precyzyjnym wypełnianiem przewidzianych do odegrania ról. Każde działanie podczas ceremonii miało dokładnie określoną wartość prestiżową. Elias (2002, 146-147) w kontekście tych zrytualizowanych działań mówi nawet o fetyszu prestiżu. Zasadnicze znaczenie tych aktów nie polegało na tym, że uczestniczące $w$ nich jednostki mogły $z$ nimi wiązać czy też czerpać $z$ nich wartości użytkowe. Jednak to, co działo się podczas nich, jednoznacznie rzutowało na pozycję społeczną jednostki w ramach figuracji dworskiej (Elias 2002, s. 147).

Podstawowe znaczenie miała bardzo sztywna etykieta. W czasach Ludwika XIV przestrzegano jej drobiazgowo, później uległa rozluźnieniu. Dostrzegano każdy niuans. To właśnie nieformalne „wypełnienie” gestami, mimiką, zdawkowymi słowami, znaczącymi spojrzeniami tej szczegółowo uregulowanej formy stanowiło probierz faktycznej pozycji jednostki. Sprzyjanie osobie, której pozycja się obniżała, było niebezpieczne; mogło nawet doprowadzić do popadnięcia $\mathrm{w}$ niełaskę u króla, a to z kolei - do utraty źródeł utrzymania. Warto było natomiast utrzymywać dobre relacje z osobami, które cieszyły się łaską króla.

Jak dokładnie działał ten samonapędzający się mechanizm, który Elias określił mianem perpetuum mobile, opisał w swych wspomnieniach książę Ludwik de Saint-Simon. Elias przytacza ten fragment, w którym arystokrata relacjonuje, w jaki sposób Ludwik XIV okazał mu niełaskę za wystąpienie ze służby wojskowej. Król nie odebrał mu przywileju uczestniczenia w coucher, ale udawał, że go nie widzi, przez trzy lata nie odezwał się ani słowem do człowieka, którego widywał niemal codziennie (por. Elias 2002, s. 154). A członkowie towarzystwa dworskiego nieustannie obserwują innych i siebie. 


\section{KONFLIKT KLASOWY W OBRĘBIE JEDNEGO STANU}

Społeczność szlachecka Francji była wielorako podzielona. Istniała nieufność między tradycyjną arystokrację rycerską a tymi dworzanami, którzy byli uszlachconymi mieszczanami, a król był zainteresowany jej podtrzymywaniem, gdyż za sprawą sprzeczności interesów obu tych warstw był w stanie zapewnić sobie „pełnię” władzy. Prócz tego podziału wyraźny i nie mniej istotny był podział na szlachtę dworską - tę, która przebywała w Wersalu i ubiegała się o wpływ na władzę w królestwie — oraz szlachtę ziemską, prowincjonalną, która stanowiła część noblesse d'épée, ale nie brała udziału w dworskim życiu. Jej dostęp do władzy królewskiej był znacznie mniejszy niż dworskiej szlachty miecza, i jej polityczne wpływy malały, przedstawiciele tej warstwy nie mieli zatem nadziei na polepszenie bytu przez uzyskanie królewskiej pensji, dochodów $z$ nowych nadań związanych $z$ dworskimi funkcjami. Wyrażali oni niezadowolenie $z$ decyzji króla, jako moralnie naganne oceniali życie na dworze monarchy i tworzyli idylliczny obraz przeszłości - czasów, w których ich warstwa stanowiła ostoję królestwa. W tej wizji ich wiejski styl życia jawił się jako właściwy.

„To, co ujawnia się w badaniu rozróżnień i konfliktów między elitami stanowymi - pisze Elias (2002, s. 123) - w nie mniejszym stopniu odnosi się do społecznej mobilności, która mimo wszelkich różnic i rywalizacji wiedzie od jednej warstwy stanowej do drugiej. Także owa mobilność, także awans i degradacja rodzin $\mathrm{w}$ ramach stanowo uwarstwionego społeczeństwa jest uwarunkowana społecznie. To znaczy, że nie stworzył ich żaden król ani żadna inna jednostka. Podobnie jak stanowy układ [Anordnung] uwarstwienia społeczeństwa, awans i degradacja są przejawami immanentnej dynamiki tej figuracji”.

Procesy te zasługują na miano walki klas, ale walki klas szczególnego rodzaju. Charakter klasowy w tym przypadku mają różne warstwy, składające się na stan szlachecki. Formalnie ich członkowie pozostają szlachcicami. Jednak mają różne pochodzenie i różne interesy. W wyniku tarć, do których dochodzi między nimi, wytwarza się nowy kształt struktury społecznej. Zmiana nie ma charakteru gwałtownego; to nie rewolucja. Jest to jednak proces dynamiczny, tak szybki, że zmiany, które generuje, są zauważalne dla uwikłanych w nie jednostek.

Proces przeobrażeń struktury społecznej francuskiej szlachty trwa od końca XV wieku. Warstwą najważniejszą przestają być wojownicy; monarcha przestaje się nimi otaczać. Życie królestwa koncentruje się na dworze - w bezpośrednim otoczeniu monarchy. Wynika to między innymi ze zmian technologicznych i ekonomicznych w dziedzinie prowadzenia wojen (por. Howard 2007, s. 31-32). Jak to podczas procesów przemian społecznych bywa, jedni awansują, a inni podlegają procesowi degradacji. Nie wszyscy, których ten proces dotyczy, zdają sobie sprawę, jakie są powody zmian. Niezadowolenie z zaistniałej sytuacji przeradza się w napięcie emocjonalne. Całe warstwy społeczne odczuwają deprywację, podczas gdy inne uważają, że zostały docenione. Po- 
czucie niesprawiedliwości dotyka przede wszystkim tych, którzy są najbardziej przywiązani są do starego sposobu życia: mieszkania na wsi, życia z uprawy roli, czerpią poczucie własnej wartości ze starych, rycerskich tradycji własnego rodu oraz głoszą gotowość do służenia monarsze bronią - ciągłe pozostawanie częścią stanu rycerskiego. Proces zmian nasila się w XVI wieku, by wejść $\mathrm{w}$ fazę apogeum w połowie XVII wieku, kiedy to, chcąc ratować swą pozycję, szlachta prowincjonalna organizuje działania zbrojne mające zniweczyć zdobycze polityczne ostatnich królów (Fronda) ${ }^{11}$. Rebelia się nie udaje, ale resentyment pozostaje i dochodzi do głosu nie tylko w sferze walki o wpływy polityczne. Jest widoczny także w obszarze kultury. Powieść Astrea Honoriusza d'Urfé (1978) jest tu chyba najbardziej symptomatyczna ${ }^{12}$. Elias wybiera tę książkę jako wyraziste odzwierciedlenie opisywanych procesów między innymi dlatego, że należała do najbardziej poczytnych, a swą popularność zawdzięczała przede wszystkim temu, że opisuje rzeczywistość społeczną (co prawda, ukazaną $\mathrm{w}$ formie fantastycznej) z punktu widzenia wiejskiej szlachty prowincjonalnej — wielkiej przegranej przeobrażeń wczesnej nowożytności.

Różne rodzaje postaci reprezentują w powieści różne kategorie społeczne: pasterze i pastereczki to szlachta prowincjonalna, wiodąca tradycyjne życie na wsi, pozostałe postaci, a przede wszystkim nimfy — to członkowie kół dworskich. Tylko na wsi można żyć w zgodzie z zasadami miłości. Dworzanie nie są do niej zdolni. Oto uzasadnienie moralnej wyższości szlachty kontynuującej rycerski styl życia nad szlachtą, która podporządkowała się dworskim porządkom. Astrea jest przeto świadectwem swoistej walki klasowej, rozgrywającej się w obrębie jednego stanu społecznego. Autor powieści był świadomy tego, że nowa struktura społeczna jest dziełem monarchy.

\section{STANY, KLASY I NAPIĘCIA SPOŁECZNE: ELIAS I MARKS}

Zasadnicza część narracji w „Społeczeństwie dworskim” kończy się wraz ze śmiercią Ludwika XIV. W kilku miejscach jednak Elias doprowadza opis aż do rewolucji 1789 roku, aby pokazać rozwój figuracji: proces, który zaczął się w XVI wieku i dobiegł końca wówczas, gdy w wyniku burzliwej serii przewrotów politycznych mieszczaństwo w pełni stało się podmiotem państwa.

Być może moment rewolucji i obalenie monarchii należy uznać za koniec figuracji dworskiej (w jej klasycznej formie), ale po okresie Rewolucji i Pierwszego Cesarstwa nastąpiła Restauracja, który to ustrój uległ przekształceniu w wyniku rewolucji lipcowej 1830 roku. I tu jest miejsce na, mam nadzieję, interesujący komentarz do rozważań Eliasa na temat składu społecznego stanu

$11 \mathrm{~W}$ połowie XVII wieku Fronda była próbą podporządkowania sobie króla i uczynienia go marionetką w gestii arystokratycznych koterii (Elias 2002, s. 218; Baszkiewicz 1992, s. 243-245).

12 Książka ta ukazywała się w częściach w latach 1608-1627 i jest uważana za pierwszą francuską powieść-rzekę. Jednocześnie jest klasycznym przykładem literatury sielankowej. 
szlacheckiego i klasowych konfliktów w jego łonie. Mamy w nich do czynienia $z$ arystokracją dworską pochodzenia rycerskiego, arystokracją i szlachtą pochodzenia mieszczańskiego zajmującą stanowiska urzędnicze oraz szlachtą prowincjonalną. Każda $z$ tych kategorii ma własny zespół wyobrażeń na temat rzeczywistości i stosunków społecznych, który można określić jako świadomość klasową. Szlachta prowincjonalna odczuwa deprywację względem warstw dworskich, w obrębie towarzystwa dworskiego arystokraci pochodzenia rycerskiego odczuwają zagrożenie ze strony arystokratów pochodzenia mieszczańskiego, ci ostatni zaś rosnąc w siłę, stale utrzymują stosunki z mieszczaństwem i z niechęcią odnoszą się do szlachty rycerskiej en bloc.

\section{KRYTYCZNA ANALIZA STOSUNKÓW SPOŁECZNYCH ELIT DWORSKICH}

Sytuacja, w której decydującą pozycję zajmował król jako arbiter i bezpośredni wykonawca kontroli społecznej w towarzystwie dworskim, została już wcześniej sproblematyzowana przez Karola Marksa w 18 brumaire'a Ludwika Bonaparte i Walkach klasowych we Francji 1848-1850.

Karol Marks w 18 brumaire'a Ludwika Bonaparte nakreśla strukturę społeczną Francji między lipcem 1830 a wiosną roku 1848, czyli rewolucją, która ponownie zniosła monarchię i wprowadziła rządy republikańskie. Oczywiście, struktura społeczna Francji w pierwszej połowie XIX wieku nie była dokładnie taka sama jak pół wieku wcześniej, jednak można sięgnąć do niej w celach analitycznych jako do swego rodzaju wzorca relacji. W opisie Marksa znajdujemy kilka pomocnych wskazówek dotyczących składu społecznego klas rządzących, ich interesów i świadomości klasowej. Opis ten wykracza poza uproszczone, modelowe rozumienie struktury społecznej, trapionej koniecznym konfliktem dwóch przeciwstawnych klas i ich interesów. W rzeczywistości Marks operuje sześcioma kategoriami klasowymi, w tym dwiema, które mają decydujący wpływ na podejmowanie decyzji w państwie (na króla). Te kategorie klasowe przecinają się z grupami interesu, których Marks wylicza dziesięć ${ }^{13}$. Bezpośredni wpływ na króla miały arystokracja finansowa oraz burżuazja przemysłowa (obie są jednocześnie kategoriami klasowymi i grupami interesu) (Hayes 1993, s. 105-106). Trzeba jednak pamiętać o tym, że Marksa interesuje cała struktura społeczna Francji, Eliasa zaś tylko warstwy wyższe i średnie.

W opisie Marksa mamy do czynienia ze specyficzną symetrią podziału frakcji klasowych: na klasy posiadające i nieposiadające. Peter Hayes (1993) nazywa

\footnotetext{
13 Wielka burżuazja, burżuazja, proletariat - produktywne, oraz arystokracja finansowa, lumpenproletariat i ludność nadwyżkowa - nieproduktywne. Grupy interesu zaś to: arystokracja finansowa, burżuazja przemysłowa, stan średni, drobnomieszczaństwo, armia, zorganizowany w gwardię lotną lumpenrpoletariat, inteligencja, klechy, ludność wiejska i proletariat (Marks 2011, s. 117).
} 
tę wizję struktury społecznej okrężną. Istnieje też drugi podział, który w poprzek przecina zasadniczy podział klasowy i komplikuje nieco rozszyfrowanie zagadnienia walki klas i realizację klasowych interesów ${ }^{14}$. Każda $z$ klas pozostających ze sobą w konflikcie dzieli się na frakcję produktywną i frakcję nieproduktywną ( $z$ wyjątkiem arystokracji, która $z$ definicji jest nieproduktywna - ten fakt ma istotne znaczenie dla rozważań prowadzonych przez Eliasa, a w Marksowskim opisie wydarzeń rewolucyjnych 1848 roku próżno jej szukać ${ }^{15}$ ). Klasa robotnicza składa się $z$ proletariatu (frakcji produktywnej) i lumpenproletariatu (nieproduktywnej). Analogicznie, burżuazja dzieli się na produktywnych przemysłowców i nieproduktywnych arystokratów finansowych. Frakcje nieproduktywne Marks uważał za zdegenerowane. Różnice między produktywnymi i nieproduktywnymi frakcjami klasowymi nie mają charakteru formalnego: opierają się na podstawach materialnych (stosunku do środków produkcji) i świadomościowych (obecności bądź nieobecności świadomości klasowej). U przedstawicieli lumpenproletariatu ów brak świadomości klasowej przejawiał się $\mathrm{w}$ dążeniu do realizacji krótkoterminowych korzyści materialnych i podatności na propagandę polityczną. To właśnie dlatego paryski lumpenproletariat stłumił powstanie robotnicze w czerwcu 1848 roku lumpenproletariusze zaciągnęli się do gwardii mobilów, ponieważ w zamian za swe zaangażowanie otrzymali żołd, z kolei arystokraci finansowi oderwali się od działań związanych $z$ procesem produkcji, a także $z$ (najszerzej rozumianą) pracą, czyli czynnościami, które wiążą się z produkcją i gospodarowaniem. Jedyne ekonomiczne zaangażowanie, na które było ich stać, to zabezpieczanie stanu posiadania poprzez działania polityczne. O ile tradycyjna arystokracja stanowiła warstwę dominującą w okresie restauracji (1815-1830), to podczas rządów Ludwika Filipa (1830-1848) dominowała arystokracja finansowa. Burżuazja przemysłowa, świadoma swych interesów klasowych, zaangażowała się w rewolucję 1848 roku i doprowadziła do utworzenia republiki burżuazyjnej. „Po burżuazyjnej monarchii Ludwika Filipa może nastąpić tylko burżuazyjna republika, tzn., że jeżeli pod firmą króla panowała ograniczona część burżuazji, to teraz w imieniu ludu panować będzie burżuazja jako całość" — zauważa Marks w 18 brumaire'a (2011, s. 117) ${ }^{16}$.

\footnotetext{
14 W 18 brumaire'a Ludwika Bonaparte nie mamy do czynienia z „całymi klasami”, lecz z sojuszami o międzyklasowym charakterze, które w dodatku wykazują pewną dynamiczność - ciągle się zmieniają (Hall 1977, s. 41-42). Świadomość własnych interesów klasowych także nie jest stabilna, co skutkuje trudnymi do odczytania aliansami międzyklasowymi.

15 Arystokracja wycofała się z życia politycznego po rewolucji w lipcu 1830 (zob. Wąsowicz 1994).

16 Pomijamy w tym miejscu dyskusję na temat ludności nadwyżkowej. W 18 brumaire'a ta kategoria klasowa wspomniana jest tylko raz, choć jest istotna dla modelu opracowanego przez Hayesa. Ludność nadwyżkowa to migranci ze wsi, którzy jeszcze nie zakorzenili się w mieście. Podobnie jak lumpenproletariat, jej członkowie zajmują prekarne pozycje społeczne (są nieproduktywni), lecz w odróżnieniu od niego nie są zdegenerowani (co upodabnia ich do proletariuszy).
} 
W Marksowskim opisie - nie jest to zresztą tylko jego zdanie - Ludwik Filip był królem słabym; nie potrafił (a może procesy społeczne, w ramach których działał nie pozwoliły mu?) utrzymać równowagi interesów między różnymi warstwami/klasami funkcjonalnymi w państwie. Stąd wybuch rewolucji, której rzecznikami byli produktywni bourgeois, a rewolucjonistami produktywni proletariusze. Ci drudzy chcieli republiki socjalnej, ci pierwsi - burżuazyjnej. Produktywny proletariat został spacyfikowany w wyniku zamachu stanu urządzonego przez burżuazję przemysłową, arystokrację finansową, stan średni i armię, a dokonanego przez lumpenproletariat, w czerwcu 1848, zaledwie pięć miesięcy od wybuchu rewolucji. Ostatecznymi zwycięzcami przewrotu stali się bourgeois; arystokracja finansowa straciła bezpośrednią moc oddziaływania na decyzje polityczne. Francuska rewolucja 1848 roku była więc kolejnym etapem likwidowania układu społeczno-politycznego, który Elias określił mianem figuracji dworskiej.

Spojrzenie na figurację dworską, którą opisuje Elias, może być bardzo interesujące, jeśli uwzględnimy dostrzeżony przez Marksa podział klas na frakcję produktywną i frakcję nieproduktywną. Istnieje dość wyraźna różnica dzieląca okres opisywany przez Eliasa i okres opisywany przez Marksa. Elias opisuje zjawisko włączania do towarzystwa dworskiego (nieproduktywnego z definicji) ludzi ze świata mieszczańskiego (produktywnego). Co prawda, financiers stanowili nieproduktywną frakcję burżuazji, ale nobilitacja sprawiła, że ich mieszczańskie, oparte na produktywności, korzenie zaczęły być dla nich ważne jako element ich tożsamości w zestawieniu z zupełnie nieproduktywną arystokracją miecza. W strukturze społecznej dworu, przedstawionej przez Eliasa, ta nowa część arystokracji odgrywa rolę - przynajmniej częściowo - frakcji produktywnej. Tymczasem Marks, chcąc oddać strukturę społeczną Francji pierwszej połowy XIX wieku, pisze o „arystokracji pieniądza”. Warstwa ta jest nieproduktywną, zdegenerowaną frakcją burżuazji, która zastąpiła nieistotną już politycznie prawdziwą arystokrację. „Arystokracja finansowa” to ta sama warstwa co bankierzy i finansiści u Eliasa, tyle że wchodząca w skład klasy burżuazyjnej. W strukturze społecznej, która uległa przemianom na skutek kolejnych wstrząsów rewolucyjnych, zachowała ona swój charakter i wpływ na władzę, jednak ze względu na zmieniony kontekst ta pośrednia warstwa jawi się $\mathrm{w}$ innym świetle.

\section{KONKLUZJE}

1. Formowanie dworu przez Ludwika XIV polegało na łączeniu elementów tradycyjnej arystokracji i uszlachconej „arystokracji pieniądza” - tej części burżuazji, która wzbogaciła się do tego stopnia, że jej przedstawiciele zajmowali się spekulowaniem i inwestowaniem posiadanego majątku. Interesowali się też bezpośrednio tym, co działo się na królewskim dworze, zwłaszcza że jego drzwi nie były przed nimi zamknięte. Skład społeczny dworzan był szcze- 
gólny pod względem strukturalnym: dostrzegł to Elias i opisał dokładnie mechanizm kontroli społecznej, który pozwolił wzorcowemu monarsze absolutnemu utrzymywać równowagę między dworską szlachtą miecza (nieproduktywną) i arystokracją pieniądza (również nieproduktywną, choć wywodzącą się $z$ mieszczaństwa i czerpiącą $z$ tego faktu opierające się na wyobrażeniu o mieszczańskiej produktywności poczucie wyższości względem tradycyjnej arystokracji o rycerskim rodowodzie).

2. Na dworze królewskim dochodzi do szczególnej odmiany walki klas: przedstawiciele mieszczańskiej finansjery są dopuszczani do stanu szlacheckiego - stają się arystokratami, ale dzieje się tak głównie za sprawą króla, który chce zrównoważyć oddziaływanie tradycyjnej arystokracji. Co prawda, nowi arystokraci szybko się asymilują, jednak pewne klasowe rezydua nie opuszczą ich jeszcze przez długi czas: między obiema frakcjami cały czas tli się resentyment, który pozwala królowi na wyważoną politykę względem obu grup. W towarzystwie dworskim wszyscy zależą od niego, także pod względem materialnym. Noblesse de robe ironicznie podchodzi do wartości wyznawanych przez noblesse d'épée. Jednak obowiązujący wysoko urodzonych (wszystkich: obu kategorii) zakaz zajmowania się działalnością zarobkową sprawia, że między obiema warstwami dochodzi do pewnej konwergencji. Gdy w czasach Ludwika XV i Ludwika XVI etykieta przestała być tak rygorystycznie przestrzegana, okazało się, że nie brakuje arystokratów uwikłanych w interesy handlowe czy inwestycyjne. Ich pozycja u schyłku ancien régime'u zbliżyła się do burżuazji. Wynikało to z konieczności: dworzanie zmuszeni byli do reprezentacyjnej konsumpcji, przez co zadłużali się, ubożeli i wypadali z towarzystwa. Dla przedstawicieli noblesse de robe tego rodzaju uwikłania były bardziej naturalne. Tak czy inaczej $\mathrm{w}$ pierwszej połowie XIX wieku tradycyjna arystokracja nie była już tą samą warstwą społeczną, co przed rewolucją 1789 roku. W zasadzie jej społeczna funkcja (tego pojęcia używam tutaj w znaczeniu, w jakim stosował je Elias) została przejęta przez arystokrację finansową — bądź co bądź warstwę klasy burżuazyjnej - gdy tymczasem prawdziwa arystokracja, ta z rycerską przeszłością, nie była już w stanie realizować swoich interesów klasowych.

3. Elias był zainteresowany badaniem człowieka - uwikłań jednostki w strukturze społecznej. W „Społeczeństwie dworskim” opisuje proces powstawania świadomości, która odzwierciedlała to umiejscowienie w strukturze społecznej. Karol Marks natomiast, pisząc 18 brumaire'a i Walki klasowe we Francji, dążył do wyjaśnienia klęski rewolucji 1848 roku i zainstalowania się kolejnego wcielenia burżuazyjnej reprezentacji politycznej. W analizie wychodzi raczej od tego, dlaczego przedstawiciele poszczególnych klas (i warstw) społecznych nie realizowali swego klasowego interesu lub dlaczego nie dążyli do jego realizacji konsekwentnie. Znajdujemy u niego pewne uwagi na temat tego, co myślał francuski proletariusz, lecz są to uwagi uogólnione, dotyczące „przeciętnego” przedstawiciela klasy społecznej. Elias zaś odtwarza doświadczenia jednostek, żeby je następnie uogólnić. Cel u jednego i drugiego myśli- 
ciela zasadniczo jest ten sam: $\mathrm{w}$ rezultacie otrzymujemy obraz strukturalnych uwarunkowań przemian społecznych. W przypadku Eliasa jest to opis dynamiki figuracji dworskiej zmierzającej ku przesileniu rewolucyjnemu 1789 roku, u Marksa - opis uwarunkowań społecznych i przebiegu wydarzeń związanych z rewolucją 1848, w krótkim okresie między rokiem 1848 a 1852. Opis Eliasa, który powstał około osiemdziesiąt lat później, jest uzupełnieniem sprawozdawczego, trochę dziennikarskiego w stylu Marksowskiego opisu „mechaniki struktury społecznej” - i dzięki temu oferuje analityczną prezentację struktury społecznej, uwzględniającą jednostkę oraz jej siłę oddziaływania na tę strukturę.

W tym sensie możemy mówić, moim zdaniem, o twórczym rozwinięciu przez Eliasa wczesnomarksowskiej wizji struktury społecznej. Oczywiście, pamiętając, że Elias musiał dojść do swego sposobu widzenia struktury społecznej za sprawą lektury Marksa, wzbogaconej o krytyczne względem Marksa odniesienia Maksa Webera - jego rozróżnienie na klasy ekonomiczne (czyli klasyczne Marksowskie ujęcie klas społecznych) i klasy kulturowe - stany społeczne (nazywane czasem warstwami ${ }^{17}$ ).

Na zakończenie chciałbym ocenić możliwe zastosowania analizy sprzecznych interesów, nie zawsze uświadamianych przez członków towarzystwa dworskiego, jako swego rodzaju modelu, który można wykorzystać w badaniach innych przemian społecznych.

Podstawową zaletą ujęcia figuracyjnego jest pominięcie podziału zjawisk społecznych na te należące do sfery makrospołecznej i te mieszczące się w sferze mikrospołecznej. Figurację dworską widzimy w jej całokształcie: widzimy procesy społeczne, które stanowią podstawę życia towarzyskiego, widzimy życie polityczne, które stanowi część życia towarzyskiego, widzimy wreszcie mechanizmy związane $z$ podziałem dóbr ekonomicznych, oczywiście $\mathrm{w}$ zakresie, $\mathrm{w}$ jakim pozostają one $\mathrm{w}$ gestii króla lub — innymi słowy — mieszczą się w obrębie figuracji dworskiej.

Drugim argumentem na rzecz zastosowania konceptualizacji figuracji dworskiej na potrzeby badań procesów przemian społecznych jest przyjęcie perspektywy długoterminowej. Figuracja, którą analizuje Elias, powstawała przez około 170 lat, od czasu gdy dały znać o sobie procesy dezintegracji średniowiecznego ładu społeczno-ekonomicznego i jego politycznej nadbudowy i zaczął rodzić się absolutyzm w Europie Zachodniej. Inaczej postrzegamy przemiany społeczne, w tym rolę jednostki, kiedy widzimy ją jako uczestniczkę zjawisk społecznych w okresie pięcio-, dziesięcio- czy nawet dwudziestoletnim, a inaczej gdy możemy obserwować przeobrażenia społeczne w perspektywie długookresowej. Wtedy pełniej dostrzegamy społeczne uwarunkowania

17 Por. dyskusję na temat problemów definicyjnych pojęcia klasy (Kozyr-Kowalski 1979, s. 11-34) oraz klasy i warstwy (Kozyr-Kowalski 1979, s. 70-76). 
działań zbiorowości (takich jak grupy interesu, warstwy i klasy społeczne) oraz jednostek, które $\mathrm{w}$ te procesy są zaangażowane bądź uwikłane.

Szczególnie owocne może być spojrzenie z pozycji jednostki. Przede wszystkim pozwala ono uchwycić oddziaływanie jednostki na strukturę ${ }^{18}$. Drugim wymiarem analizy jednostki w ramach figuracji jest bliższe rzeczywistości, modelowe przedstawienie struktury powiązań, które ograniczają działania jednostki, wyznaczając jednocześnie zakres jej oddziaływania. To ogólny aspekt Eliasowskiej koncepcji figuracji, obecny nie tylko w „Społeczeństwie dworskim” (por. np. Elias 2006). Ten jednostkowy wymiar analizy struktury społecznej ważny jest także z trzeciego powodu (w zasadzie występującego u Marksa). Jest nim wymiar świadomości jednostek działających w konkretnych układach społecznych (tu: figuracjach). Zagadnienie to jest interesujące, zwłaszcza gdy mamy do czynienia z dynamiczną zmianą społeczną. $\mathrm{W}$ takich okolicznościach zmianom ulegają również kanały dystrybucji wie$\mathrm{dzy}$ - w zależności od usytuowania $\mathrm{w}$ ramach figuracji jednostka ma lepszy czy gorszy dostęp do wiedzy na temat zachodzących procesów lub nie ma go wcale. I na tej podstawie podejmuje działania. W opisie Eliasa przejawia się to w zwiększonym zainteresowaniu osiemnastowiecznych arystokratów działalnością „mieszczańską” (wbrew regułom obowiązującym dworzan, ponieważ etykieta oraz obostrzenia jej towarzyszące utraciły już status podstawowego regulatora zachowań towarzyskich i mechanizmu kontroli społecznej w rękach króla). Nie dziwi chyba, że ten wymiar świadomościowy jest mocno wyeksponowany w pismach Karola Marksa. W 18 brumaire'a mamy proletariuszy, którzy sięgają po broń i wzniecają rewolucję, wyobrażając sobie, że porewolucyjna Francja będzie republiką ludową. Marks pisze, że każda klasa inaczej wyobrażała sobie porewolucyjne państwo, ale najmniej zyskali na przewrocie właśnie robotnicy. Działali bowiem powodując się dalece nieprecyzyjnymi informacjami i po prostu dali się oszukać burżuazji, która przed rewolucją i tylko przed nią — zainteresowana była przymierzem z proletariatem.

Wszystko to wskazuje na przewagę takiego ujęcia uwarunkowań działań społecznych jednostek, które uwzględnia zrekonstruowaną figurację oraz zakres wiedzy stanowiącej podstawę działań nie tylko jednostkowych, lecz także zbiorowych.

\section{BIBLIOGRAFIA}

Baszkiewicz Jan, 1992, Francuski absolutyzm w XVII wieku, w: Antoni Mączak (red.), Europa i świat w początkach epoki nowożytnej, cz. 2, Wiedza Powszechna, Warszawa.

Bogner Artur, 1987, Elias and the Frankfurt School, „Theory, Culture and Society”, t. 4, s. 249-285.

$18 \mathrm{~W}$ opisie Eliasa najlepiej widać sprawczość Ludwika XIV jako „osoby zajmującej pozycję króla” (Elias 2002, s. 123, zob. wyżej cytowany fragment). Użycie tego sformułowania ukazuje dobitnie, że autor nie traktował rządów Ludwika XIV jako wydarzenia wyjątkowego, lecz jako model sprawowania władzy poprzez mechanizm królewski. 
Bucholc Marta, 2013, Samotność dtugodystansowca. Na obrzeżach socjologii Norberta Eliasa, Wydawnictwo Naukowe PWN, Warszawa.

Burke Peter, 2011, Frabrykacja Ludwika XIV, tłum. Robert Pucek, Michał Szczubiałka, Wydawnictwa Uniwersytetu Warszawskiego, Warszawa.

Choiński Krzysztof, 1978, Wstęp, w: Honoré d’Urfé, Astrea, Czytelnik, Warszawa.

D’Urfé Honoré, 1978, Astrea, tłum. zbiorowe, Czytelnik, Warszawa.

Elias Norbert, 2002 [1969], Die höfische Gesellschaft. Untersuchungen zur Soziologie des Königtums und der höfischen Aristokratie, Suhrkamp Verlag, Frankfurt am Main.

Elias Norbert, 2006, Mozart. Portret geniusza, tłum. Bogdan Baran, Wydawnictwo W.A.B., Warszawa. Elias Norbert, 2010, Czym jest socjologia?, tłum. Bogdan Baran, Aletheia, Warszawa.

Elias Norbert, 2011, O procesie cywilizacji. Analizy socjo- $i$ psychogenetyczne, tłum. Tadeusz Zabłudowski, Kamil Markiewicz, Wydawnictwo W.A.B., Warszawa.

Hayes Peter, 1993, Marx's Analysis of the French Class Structure, „Theory and Society”, t. 22, s. 93-113. Howard Michael, 2007, Wojna $w$ dziejach Europy, tłum. Tadeusz Rybowski, Ossolineum, Wrocław. Kilminster Richard, 2007, Norbert Elias: Post-philosophical Sociology, Routledge, London-New York. Käsler Dirk, 2010, Max Weber. Życie i dzieło, tłum. Sława Lisiecka, Oficyna Naukowa, Warszawa. Kozyr-Kowalski Stanisław, 1967, Max Weber a Karol Marks. Socjologia Maxa Webera jako „pozytywna krytyka materializmu historycznego", Książka i Wiedza, Warszawa.

Kozyr-Kowalski Stanisław, 1979, Klasy i stany. Max Weber a wspótczesne teorie stratyfikacji spotecznej, Państwowe Wydawnictwo Naukowe, Warszawa.

Kuzmics Helmut, 1987, Civilization, State and Bourgeois Society: The Theoretical Contribution of Norbert Elias, „Theory, Culture and Society”, t. 4, s. 515-531.

Löwith Karl, 1993, Karl Marx and Max Weber, Routledge, London-New York.

Mannheim Karl, 2008, Ideologia i utopia, tłum. Jan Miziński, Aletheia, Warszawa.

Marks Karol, 2011, 18 brumaire'a Ludwika Bonaparte, Wydawnictwo Krytyki Politycznej, Warszawa.

Marody Mirosława, 2008, O socjologii Norberta Eliasa, w: Norbert Elias, Społeczeństwo jednostek, tłum. Janusz Stawiński, Wydawnictwo Naukowe PWN, Warszawa.

Monteskiusz, 1997, O duchu praw, tłum. Tadeusz Boy-Żeleński, Antyk, Kęty.

Nagbøl Søren, 2012, Norbert Elias and the Frankfurter Traditions, „Cambio”, nr 4.

Saint-Simon Louis de Rouvroy, 1961, Pamiętniki, t. 1, tłum. Aleksander i Maria Bocheńscy, Państwowy Instytut Wydawniczy, Warszawa.

Szakolczai Árpád, 2005, Elias and the Re-founding Social Theory: A Comment, „Current Sociology”, t. 53, s. 829-834.

Taine Hipolit A., 1881, Francya przed rewolucya, tłum. Piotr Chmielowski, Edward Grabowski, Nakład i druk S. Lewentala, Warszawa.

Tönnies Ferdinand, 1988, Wspólnota $i$ stowarzyszenie, tłum. Małgorzata Łukasiewicz, Państwowe Wydawnictwo Naukowe, Warszawa.

Wąsowicz Marek, 1994, Między tronem, giełda i barykadą. Francja 1830-1848, Wydawnictwo Omnia, Warszawa.

\section{CLASS STRUGGLE IN COURT SOCIETY}

\section{Summary}

The article discusses the social differentiation of the elite at the French court in the era of absolutism, as depicted by Norbert Elias in his book Die höfische Gesellschaft [The Court Society]. The internal struggles of this elite are presented as a special form of figuration, which Elias calls 'court figuration' to indicate the processual nature of 
the phenomenon. The departure point for the author of the article's further reflections is the premise that these conflicts are similar to class struggle in the Marxist sense (particularly the analyses contained in Marx's earlier writings). As a result, figurational analysis, based on Elias's historical sociology, is shown to be a particularly useful category in studying the social differentiation lying at the base of social change, that is, in analysing both long-term processes of social change and rapid processes of a revolutionary character.

\section{Key words/słowa kluczowe}

Norbert Elias; Karl Marx / Karol Marks; figuration / figuracja; class struggle / walka klas; court society / społeczeństwo dworskie; historical sociology /socjologia historyczna 